\title{
Analysis of the Strategy of Chinese Enterprises to Open up Vietnam Market-A Case Study of a Hong Kong Invested Enterprise Entering the Vietnamese Market
}

\author{
Zhen Li, Nguyen Thi Thu Ha \\ School of Business Administration, South China University of Technology, Guangzhou, China \\ Email: 201620124200@mail.scut.edu.cn
}

How to cite this paper: $\mathrm{Li}, \mathrm{Z}$. and $\mathrm{Ha}$, N.T.T. (2017) Analysis of the Strategy of Chinese Enterprises to Open up Vietnam Market-A Case Study of a Hong Kong Invested Enterprise Entering the Vietnamese Market. Open Journal of Business and Management, 5, 699-709.

https://doi.org/10.4236/ojbm.2017.54058

Received: September 29, 2017

Accepted: October 28, 2017

Published: October 31, 2017

Copyright $\odot 2017$ by authors and Scientific Research Publishing Inc. This work is licensed under the Creative Commons Attribution International License (CC BY 4.0). http://creativecommons.org/licenses/by/4.0/

\section{Open Access}

\begin{abstract}
Under the background of economic globalization, the concept of "global village" is constantly strengthened, and the links between countries are becoming more and more closely. More and more Chinese enterprises have stepped into the world. After the 2008 financial crisis, there were signs of recession and weakness in the European and American markets, and many Chinese enterprises began to turn their attention to the Southeast Asian market, which had not yet been saturated, and hope to win the competition through geographical advantages and price advantages. China and Vietnam are neighbors, are similar in political systems and cultural, but Chinese enterprises are often failed to develop Vietnam market. How to accurately grasp the characteristics of the Vietnamese market, and how to improve the effectiveness of enterprise market development, based on this, this passage is written for Chinese enterprises to explore similar features of the market to provide reference experience. This article is written through a Hong Kong LED lighting enterprises to develop the Vietnamese market successful experience, and put forward new strategies and new ideas for Chinese enterprises to open up the Vietnamese market.
\end{abstract}

\section{Keywords}

Chinese Enterprises, Vietnam Market, Location Advantage, Product Life Cycle

\section{Introduction}

Since the reform and opening in 1986, Vietnamese level of opening to the outside 
world has been improving continuously, the total volume of import and export trade has been increasing continuously, and the economy has developed rapidly. It has become one of the most potential developing countries in Southeast Asian countries. In 2010, the China ASEAN free trade area was formally launched, which provided a new opportunity for the trade between China and Vietnam, and further strengthened bilateral economic and trade cooperation. In the context of the further reduction of tariffs and the liberalization of mutual investment, Chinese enterprises have been racing to open up the Vietnamese market and expand export trade. According to customs statistics, in September 2015, China's bilateral trade with Vietnam totaled \$7 billion 704 million, rose $7.49 \%$ year on year. Among them, China of Vietnamese exports $\$ 5$ billion 542 million, rose $8.62 \%$ year on year, Electronic products accounted for the largest, the exports amounted to $\$ 1$ billion 241 million, rose $13.17 \%$ year on year; followed by mechanical products, exports of $\$ 573$ million, rose $0.6 \%$ year on year; and the iron and steel, exports of $\$ 367$ million, dropped $0.48 \%$ year on year [1]. Customs statistics show that between January 2015 and December, Vietnam and China's total trade amounted to 95 billion 976 million dollars, Vietnam has become China's second largest trading partner in ASEAN [2].

Although the Vietnamese market has great potential for consumption [3], many Chinese enterprises crashed in Vietnam market [4] [5]. Especially small and medium enterprises, if not to explore the Vietnamese market marketing strategy, don't pay attention to the local market and the local characteristics of Vietnam talent supply and demand situation, it would increase the cost of enterprises to explore the Vietnamese market, and lose competitiveness of enterprises, resulting in the failure of overseas strategic layout Chinese enterprises stationed in Vietnam. Therefore, this paper attempts to analyse and review NeoNeon lighting company (Hong Kong enterprises) for the experience of this enterprise entering the Vietnamese market, analysis of the enterprise in the market to enter Vietnam two stage process, refine common problems found and the corresponding effective measures when Chinese key enterprises explore the Vietnamese market. Finally, the case study summarizes typical marketing strategies and provides a reference for further China enterprises to enter the Vietnamese market.

\section{Theoretical Basis}

Product life cycle theory, also called product life theory, was proposed by Raymond Vernon, a professor at Harvard University. He believes that technological gap between countries is one of the important reasons for international trade [6]; Welsh (L.T.wells) and others have developed on this basis. It is a dynamic theory, which combines cycle theory with international trade theory [7].

The product life cycle refers to the introduction period, growth period, maturity stage and decline period. The life cycle of international trade products is divided into four stages, as shown in Figure 1. 


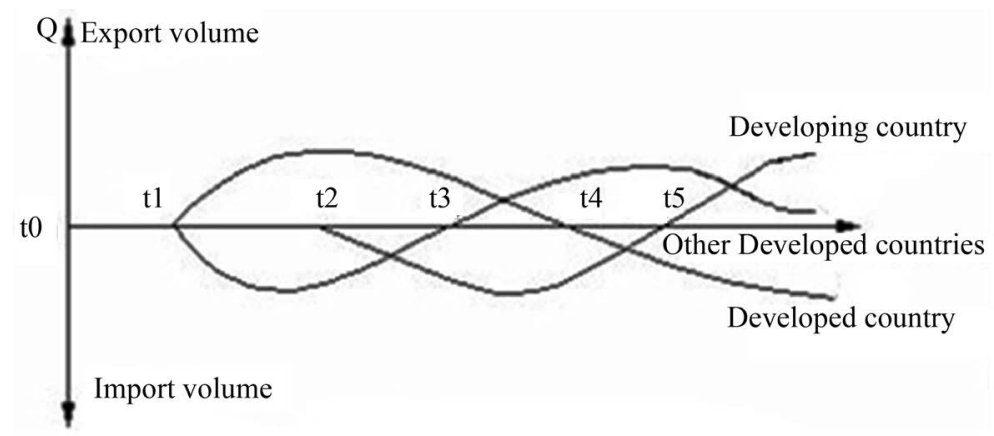

Figure 1. Dynamic change of product life cycle in international trade. (source from: http://wiki.mbalib.com).

0-T0: Innovation in developed countries has the big market, high level of scientific and technological personnel, the introduction of new products, new product launch stage, manufacturers need to get feedback from the market, in order to further improve the product, need to be close to the market, this stage only in domestic sales.

T0-Tl: New products began to export, and innovative country become a net exporter of new products, the new technology is becoming more perfect and standardized, foreign manufacturers began to imitate the innovation in products decline in the country's competitiveness.

Tl-T2: Foreign countries began to imitate and export to third countries, while the export of innovation countries was greatly reduced.

T2-T3: The advantages of developing countries in labor wages is losing, the technical gap with developed countries is narrowing. Developed countries transfer technology or direct investment to developing countries, and developing countries begin to export such technologies.

T3 and beyond: Developing countries become the world's leading exporters and exporters [8] [9].

The product life cycle in different technical level countries, the time and the process is not same, there is a large difference, this difference of different countries is technology gap, on the one hand, it reflects how comparative advantage from a state transfer to another country; on the other hand, it reflects the difference of position in the market competition in different countries on the same product, so as to determine the changes of international trade and investment. It is of guiding significance for the backward countries (regions) to determine their position and participation in the international division of labor, and how to upgrade and upgrade the industrial structure in the process of development.

\section{Research Methods and Case Selection}

\subsection{Research Methods}

Case studies apply to answering questions like "what" or "why" [10]. When the research object is in a situation in the real environment, when the researcher does not control or can not control the research object, the case study is a very 
appropriate research method [11] Based on this consideration, this study takes the Neo-Neon lighting company as an example to analyze its process and strategy of opening up the Vietnamese market. The case analysis of enterprise, mainly using semi-structured interviews and literature analysis method: firstly, semistructured interviews can get real and effective first-hand information from interviews, This study interviewed Huang Daiping, Asia manager of silver rain lighting company, interview time is about 1 hours, the formation of a 1500 word interview manuscript; secondly, literature analysis and semi-structured interviews to complement each other, analysis of the document contains a large number of documents, such as business information, business publications; issued the laws and regulations, rules and regulations and the related documents by the CPC Central Committee and the State Council, Guangdong Province; and the media, the Internet, social networking platforms (such as Neo-Neon Lighting Co. Ltd. WeChat) the number of public reports and social evaluation. Finally, through sorting out and summarizing, summed up the practice of Neo-Neon lighting company to open up the Vietnamese market practice.

\subsection{Case Selection}

On the choice of case, on the one hand, we should take into account the scale and effectiveness of the export enterprises, because such enterprises are more representative. On the other hand, because of the market research in Vietnam, we must take account of the market development of the enterprises in Vietnam. These two factors are taken into account, this research selects Neo-Neon Lighting Co. Ltd. as the research object, to explore the mechanism of developing Vietnamese market.

Neo-Neon lighting is a subsidiary of Hong Kong Neo-neon group, which is the only company in the world in the same industrial area to complete the LED vertical field of integration of resources of the listed company, specializes in design and development, production and sales of the LED light source for general lighting, commercial lighting and consumer retail is DIY lamps, is one of the world's largest supplier of decorative lamp. Neo-Neon lighting marketing network covers more than 100 countries and regions around the world, gradually transforming from the traditional lighting manufacturers to new white light LED solid-state lighting manufacturers, and become a global leader in LED lighting applications. With the widespread application of LED lighting in the global market and the rise of emerging markets, Neo-Neon lighting has begun to open up the Vietnamese market, and also faces opportunities and challenges in the process of entry. Therefore, this study selected Neo-Neon lighting company as the research object, which has a typical representative significance.

\section{Case Analysis}

\subsection{A Brief Review of the Company's Expansion of the Vietnamese Market}

Early in the market development, Silver rain lighting company as early as 1996 
in Vietnam set up production and processing plant in Taiping Province, Vietnam. At that time, the construction of factories in Vietnam mainly focused on the rich labor resources and low labor costs in Vietnam, and the production cost was the most important driving factor. Because Vietnam's economic level was relatively backward and the market scale was smaller, the main products were traditional lighting products, and the market coverage of LED lighting was relatively low. Therefore, the Vietnamese branch basically ignored development and sales market in Vietnam, even there was no market development or product sales in the Department set, Neo-Neon lighting Vietnam branch failed to LED industry in Vietnam early development, the use of huge resources and geographical advantages, ahead of the layout of the market, missed the first opportunity to enter the Vietnam market, lost the huge advantage ahead which it had. In the last ten years, LED lighting industry rose rapidly, the product demand from advanced countries in Europe and America is high, the market is mature, Neo-Neon lighting would be the main market in the developed countries, long neglected developments in emerging Asia and Africa market. With the LED lighting industry went through recession in 2012, due to the speed of development of the developed countries in Europe and America economic slowdown, mainly rely on the European and American markets Neo-Neon lighting was very careful to go through this difficult period. Business leaders were turning their attention to emerging markets in Asia and Africa, particularly the rapidly growing ASEAN market, specially Vietnam market, as shown in Table 1.

\subsection{The Successful Experience of the Company Entering Vietnam}

Neo-Neon lighting company successfully opened the Vietnam market and achieved good results. Neo-Neon lighting Vietnam market sales in 2011 is 15000 dollars, Vietnam market sales in 2012 is 3000 dollars. All Customers were

Table 1. The process of silver rain lighting company entering the Vietnamese market.

\begin{tabular}{|c|c|c|c|c|}
\hline Time & Stage & Environment & Event & Result \\
\hline 1996 & $\begin{array}{l}\text { Initial stage of } \\
\text { market } \\
\text { development }\end{array}$ & $\begin{array}{l}\text { Vietnam's economic level is } \\
\text { backward, pilot production scale is } \\
\text { small, the main products are } \\
\text { traditional lighting products, and } \\
\text { LED lighting market coverage is low. }\end{array}$ & $\begin{array}{l}\text { Silver rain lighting company in Taiping } \\
\text { Province, Vietnam set up production and } \\
\text { processing plants, mainly in Vietnam } \\
\text { fancy rich labor resources and low labor } \\
\text { costs, so it can reduce production costs. }\end{array}$ & $\begin{array}{l}\text { Silver rain lighting company ignored } \\
\text { the Vietnam market, missed the lead }\end{array}$ \\
\hline $\begin{array}{l}1997- \\
2011\end{array}$ & $\begin{array}{l}\text { Market maturity } \\
\text { stage }\end{array}$ & $\begin{array}{l}\text { LED lighting industry rapidly } \\
\text { rising, Europe and the United } \\
\text { States and other developed } \\
\text { countries, LED lighting products } \\
\text { demand is enormous. }\end{array}$ & $\begin{array}{l}\text { Silver rain lighting company put the main } \\
\text { market in developed countries. }\end{array}$ & $\begin{array}{l}\text { Silver Rain Lighting company has } \\
\text { mainly developed its market in de- } \\
\text { veloped countries, and has neglected } \\
\text { the development of emerging Asia } \\
\text { and Africa market for a long time. }\end{array}$ \\
\hline $\begin{array}{l}2012- \\
2015\end{array}$ & Winter stage & $\begin{array}{l}\text { Developed countries in Europe } \\
\text { and America have slowed down } \\
\text { their economic development. }\end{array}$ & $\begin{array}{l}\text { Silver rain lighting has turned its } \\
\text { attention to the emerging markets in Asia } \\
\text { and Africa, especially the rapidly } \\
\text { developing ASEAN market, the } \\
\text { Vietnamese market has attracted } \\
\text { much attention. }\end{array}$ & $\begin{array}{l}\text { In } 2013 \text {, after silver rain lighting } \\
\text { company's strategic adjustment, the } \\
\text { performance soared to } \$ 250,000 \text {, } \\
\text { exceeding the sum of } 2011 \text { and } 2012 \text {. }\end{array}$ \\
\hline
\end{tabular}


engineering customers which were Spontaneous. After adjusting market development strategy in 2013, the performance in 2013 soared to 250,000 dollars, and the performance was 10 times more than in the total of 2011 and 2012. The company has been developing so rapidly in Vietnam, and there are some lessons to be learned from.

\subsubsection{Analysis from the External Environment}

In 2006, Vietnam supported by the United Nations Development Programme (UNDP) and the Global Environmental Fund (GEF) funded Vietnam Efficiency of Public Lighting Exhibition Project (VEEPL) to provide technical assistance, started to invest 700,000 dollars in the efficiency of public lighting. The Ministry of Commerce and industry will set up another project to continue the plan of using high efficiency light instead of core filament bulb. It is scheduled to adopt LED electric lamps extensively in 2014. In addition, according to the Vietnam Ministry of Construction announced the "2011-2020 year national urban development plan" draft content, by 2020 , Vietnam urbanization rate is expected to increase from the current $27 \%$ to $45.2 \%$. Thus, with the Vietnamese government subsidies to support the efficient of public lighting and city of the implementation of the plan, Vietnam folk LED lighting products and LED indoor and outdoor lighting demand project ushered in blowout, Chinese LED lighting products exported to Vietnam market will usher in the golden period [12].

In the past two years, China has exported a large number of LED lighting products to Vietnam, and the trade market between China and Vietnam has expanded rapidly. Vietnam has become China's largest ASEAN exporter of LED lighting products. According to GSC (Guangdong Solid State Lighting Industry Innovation Center) statistics, in 2014, China's total exports of Vietnamese LED lighting products has reached more than 900 million dollars, the export ranking in Vietnam ranked third, is next only to the United States market and the Russian market. From the distribution of Vietnam imported LED lighting products in the international market from January 2014 to November, Vietnam imports more than 99\% LED lighting products from China, in other words, China with absolute advantage to become the largest importer of Vietnamese LED product [13], this shows that Vietnam's dependence on China's economy is unusually high. As can be seen from the data, the Vietnamese market for higher performance of China's LED lighting products acceptance is also very high. With the Vietnamese government to vigorously promote the use of new energy-saving lamps and favorable policy support, coupled with the development of economy, the Vietnamese people's consciousness of environmental protection and energy saving are gradually awakening, the LED lighting industry also increased development opportunities in Vietnam.

Vietnam as an emerging market, with the domestic industrial and civil infrastructure continues to improve, the development of the market gradually standardized, Vietnam which is an emerging market has development potential fully, this is an important driving force of domestic related industries and enterprises 
have developed the Vietnamese market. The two countries geographical advantages and give many conditions of preferential policies to create a favorable external environment for Chinese enterprises to explore the international market, with "China Belt and Road Initiative" and a new round of international cooperation in implementation of the strategy of double favorable policies to lay a tonic for Chinese LED manufacturers continued to seize the market in Vietnam. Therefore, Neo-Neon lighting made full use of existing external environment support, while LED lighting products in Vietnam's market is very broad, these factors prompted Neo-Neon lighting actively to formulate the Vietnamese market strategy.

\subsubsection{Analysis from the Internal Level}

Neo-Neon lighting company has been able to successfully enter the Vietnamese market, is related to the company's internal implementation of a series of strategic reforms.

First, the implementation of the administrative system reform. In the late stage of market development, Neo-Neon lighting has made a series of adjustments for the development of Asia and Africa market. Because of the company's long-term market in developed countries, the dependents setting and market development strategy in developing countries of Asia and Africa are relatively simple, even a person in charge markets of several countries (or region) in Asia and Africa, and the market development strategy is lack of pertinence, customer resources have not been effectively developed, post customer maintenance and management ability need to be improved. Therefore, the reform of department setting and the adjustment of administrative structure are imperative. The leadership of the company will be the first to enhance the construction of the African market branch related to the company's strategic level. Reforming will focus on the African market development department, marketing department of Asian and African refinement structure, Especially the Southeast Asian market, Indonesia is as the center to develop the market, in particular the creation of the Vietnamese market commissioner and the development and investment on the market in Vietnam.

Second, implementing the strategy of localization of talents. Before the adjustment of the administrative structure, the Vietnamese market and other markets in Southeast Asia belong to one department, and the development staffs are mainly in English. Southeast Asian countries, although all can be used in English, but each country has its own national language, if the same, English will seem less than targeted, but also difficult to let the customer trust and further communication intention in Vietnam this focus on human and relationship marketing countries, this situation is particularly evident. Therefore, the original market developer has many deficiencies in the management of the Vietnamese market, nor can develop potential customers in-depth. Therefore, the local people should be appointed as much as possible in the process of developing the international market, and they can communicate with customers without obstacles, 
and build up the trust foundation of clients quickly. Neo-Neon lighting hired who live in China or study, and familiar with China's Vietnamese as the Vietnamese market development leader through online recruitment, and finally achieved results, it proved this method is effectiveness.

Third, paying attention to personnel training. Training foreign employees is important for a company. Because most foreign employees may not have experience in the industry, coupled with language barriers and cultural differences, how to let them quickly integrate into the company and understand the process, rapid market development investment work, enterprises need to solve the problem. Relative to Vietnam and other developing countries, China has greater advantages in enterprise management and marketing, foreign employees have the company headquarters hardware and software support, business capacity has been rapidly improved.

Neo-Neon lighting park has a complete production chain from LED production, chip manufacturing to shell production, assembly, manufacturing, packaging, export and so on, for new hires, especially foreign employees to learn about LED knowledge, familiar with the company's product features and has a very big advantage. In business development, Chinese executives can keep control of the progress of the development of area business, get feedback immediately after the adjustment plan, guide and assist foreign staff to handle related business, let them get rapid improvement in business ability. Due to the rapid development stage of Vietnam coincided with the LED industry, the company adopts the Vietnamese management development in Vietnam has innate advantages. Chinese modern marketing approach combined with Vietnam's local conditions and customs, it makes business more smoothly, and the Vietnamese market has gradually become one of the company's key support business.

\subsubsection{Analysis from the Theoretical Level}

According to product life cycle theory, Neo-Neon lighting company's LED lighting products also have a competitive advantage. LED lighting started in 1960s, LED products in developed countries have been developed for 50 years, and China's LED industry has gone through more than 30 years. The enterprises in China's LED industry are growing day by day, and the competition is fierce. Because LED lighting technology is becoming more perfect and standardized, according to the theory of product life cycle, the products have been developed from the T2 stage of the product life cycle to the T3 stage, because of Vietnam's low labor costs, a vast market, it is also for this reason, Neo-Neon lighting company decided to invest in production and export market of Vietnam. After T3, the company's products will become the main export products of developing countries or regions, and there is the possibility of exporting to developed countries. This is also the guiding principle of product life cycle theory. In addition, the company also considers Vietnam as a regional advantage for China and a huge demand for the product in Vietnam. And Vietnam's political history is very similar to China, the investment risk is relatively small, Chinese companies 
are relatively easy to explore the market.

\section{Conclusions}

It is not difficult to find out how silver rain lighting develops Vietnamese market, for opening up new international markets, it is crucial to make adequate market research and understand the differences between the two countries. Chinese enterprises need to find the best entry point to enter the Vietnamese market, while the success of Neo-Neon lighting in addition to its own correct decision-making, but also with the Vietnamese market policy and economic benefits are inseparable. Now the Vietnam economic development level is low, the long-term economic development still belongs to developing countries, taking agriculture as the main industry, therefore related to agricultural machinery enterprises can be considered to enter Vietnam, especially the machine (fertilizer research and development, modernization of agriculture machinery, harvester, rice transplanter etc.), the development of marine resources and so on, there may be a larger market potential.

Secondly, Chinese enterprises should do preparatory work in the early stage, such as fully understanding the laws and regulations of Vietnam, such as the foreign investment laws, and timely follow up the Vietnamese national conditions. Vietnam is in the transition from a planned economy to a market economy, and in the day-to-day economic and trade activities, government behavior is still dominant. Private enterprises in Vietnam investment registration process is still very strict, investment projects procedures is cumbersome, approval cycle is long. In addition, the current policy of Vietnam does not allow foreign companies to register more in the establishment of trading companies. If Chinese companies want to engage in trade business in Vietnam, they must set up a Vietnam office in the present stage, and cooperate with the Vietnam local company, and the company is so easy to lose the initiative in Vietnam market development, because the Vietnamese companies are more familiar with the Vietnamese market and have rich resources. It can also be seen that Vietnamese employees play an important role in Vietnam market development, especially those who are familiar with the Chinese and Vietnamese cultures and national conditions.

However, this research studies Neo-Neon lighting deeply. In the Vietnamese market development process, we can see that many Chinese enterprises tends to ignore the training of Vietnamese cadres in the Vietnamese market development, and there is no employees training promotion mechanism for Vietnamese cadres, especially in the enterprise executives, Vietnamese executives scanty. This fact limits the further development of enterprises in Vietnam. From labor relations, Chinese enterprises tap the talent Vietnamese students from China, because of the differences between the two countries, they are familiar with the cultural and economic level, especially the Vietnamese students are easy to build trust and good relations of cooperation in communication with customers in 
Vietnam. But if Vietnamese employees can not be promoted in the process of market development and they can only be workers for a long time, they can't help but produce unpleasant voices, which will affect the communication and cooperation with Vietnamese customers.

The main contribution of this paper is, first of all, to enrich the theory of product cycles in international trade. This theory was successfully implemented in the American market. This paper selected the silver rain lighting entered the Vietnamese market as the research object, from developed countries to developing countries this change, greatly enriched the international trade theory of product cycle. Secondly, the article analyzes the process of China enterprises entering the Vietnamese market, and puts forward some corresponding suggestions, such as the Vietnamese employee employment is particularly important, can share the successful experience of the enterprise to sort out in Vietnam. Third, this paper studies the silver rain lighting company to enter the Vietnamese market, to provide guidance and reference for Chinese enterprises to enter the Vietnamese market. Finally, there are still some deficiencies in this paper, the study is only a research into Vietnam enterprise, whether the experience of this enterprise is universal in other enterprise applications, it needs to be further verified. Subsequent studies can use multiple case study methods to extend this study to more contexts.

\section{References}

[1] Xieliqing (2017) In September 2015 China and Vietnam Bilateral Trade Volume Growth of 7.5\% - Chinese ASEAN Customs Data-ASEAN Market Dynamic Monitoring of Energy-Caexpo.

http://customs.caexpo.com/data/country/2015/10/29/3653234.html

[2] Xieliqing (2017) From January 2015 to December China-Vietnam Key Products Import and Export Trend Analysis-China ASEAN Customs Data-Dynamic Monitoring of the ASEAN Market-Caexpo.

http://customs.caexpo.com/data/country/2016/04/11/3660141.html

[3] Lujing, Z. (2014) A Survey of the Survival of Chinese Enterprises in Vietnam. China Economic Weekly, No. 20, 33-35.

[4] Da, Y. (2008) How to Invest in Vietnam Is Embarrassed. Textile Business Week, No. 40,44

[5] Yun (1998) Foreign Investment in Vietnam Nearly 20\% Failed. South East Asia Information, No. 8, 7 .

[6] Vernon, R. (1982) International Investment and International Trade in the Product Cycle. International Economics Policies \& Their Theoretical Foundations, 8, 307-324. https://doi.org/10.1016/B978-0-12-444280-1.50020-3

[7] Wells, L.T. (1968) A Product Life Cycle for International Trade? Journal of Marketing, 32, 1-6. https://doi.org/10.2307/1249754

[8] Yong, L. and Yuee, L. (2010) Modern International Trade Theory and Policy. Lixin Accounting Press, Shanghai.

[9] Shushuang, W. (2006) Analysis of the Status of Yunnan Small and Medium Sized Enterprises Entering Southeast Asia and Countermeasures. Kunming University of Science and Technology, Kunming. 
[10] Yin, R.K. (2004) Case Study Research: Design and Methods. 3rd Edition, Chongqing University Press, Chongqing.

[11] Kun, Q. and Xiaolei, M. (2008) On the Integration of Case Study and Quantitative methods. Management Case Studies and Reviews, 1, 62-67.

[12] Tiemalaoyan (2017) Market Analysis of Chinese LED Lighting Products Exported to Vietnam-OFweek.

http://lighting.ofweek.com/2015-03/ART-34002-8420-28941399.html

[13] Tiemalaoyan (2017) In 2014, China's LED Lighting Products Ranked TOP10. http://www.qianjia.com/html/2015-03/19_246043.html 